\title{
A STUDY OF PHYSICAL AND ANATOMICAL CHARACTERISTICS OF THE HEAVY METAL ACCUMULATION OF JUNCUS RIGIDUS DESFONTAINES, 1798 (FAMILY, JUNCACEAE) IN BASRAH PROVINCE, SOUTHEREN OF IRAQ
}

\author{
Shatha Mohammed Hamza* Sahar A. A. Malik Al-Saadi* \\ and \\ Dunya A. Hussain Al-Abbawy** \\ * College of Science, Department of Biology, Basrah University, Basrah, \\ Iraq \\ ** College of Science, Department of Ecology, Basrah University, Basrah, \\ Iraq
}

*Corresponding author: saharmalik2010@gmail.com

Received Date: 07 January 2020, Accepted Date: 11 April 2020, Published Date: 24 June 2020

\section{ABSTRACT}

This study was carried out to determine the heavy metal accumulation of Juncus rigidus Desfontaines, 1798 from three different regions of the Basrah Province in Southern of Iraq. Specifically, the concentrations of lead, nickel, and cadmium were determined in the roots, culms and leaves of the plant. The results indicated that the highest accumulation of the heavy metal was recorded in lead $(\mathrm{Pb}) 12.50 \pm 3.58 \mathrm{mg} \mathrm{kg}^{-1}$ and then in nickel $(<0.30)$. The lowest value was recorded for cadmium $(<0.05)$. As well, lead concentrations in J. rigidus varied in different locations and parts of the plant from undetectable in control to 12.66, 19.33, and $9.80 \mathrm{mg} \mathrm{kg}^{-1}$ in leaves, culm, and roots respectively from Station 2, and 10.76, 12.66, and $9.50 \mathrm{mg} \mathrm{kg}^{-1}$ in Station 3. The values of translocation factor (TF), bioconcentration factor (BCF), and Biological Accumulation Coefficient (BAC) were greater than $>1$ used to the ability of $J$. rigidus for both phytoextraction and phytostabilization.

The anatomical analysis showed that heavy metal accumulation in plant tissues led to a reduction in root and culm thickness; in polluted area it has been found that cortex and intercellular spaces in aerenchyma layers were deceased in size, whereas high pollution levels were observed in vascular bundles, which were smaller, and had increased sclerenchyma, as well as appeared more black or dark color compared to the specimens grown in the control area.

Keyword: Accumulation, Anatomy, Culm, Heavy metals, Juncus rigidus, Root. 
A study of physical and anatomical characteristics

\section{INTRODUCTION}

The genus of Juncus Linnaeus, 1753 belongs to the family of Juncaceae, which has approximately 250 - 300 species worldwide. Among the flora of Iraq, this genus has six subgenera (Juncus, Genuini, Subulati, Pseudotenageia, Poiophylli and Septati), is widely distributed, and has 16 species. Juncus, commonly called rushes or samar, is a perennial plant; all of its leaves are basal; terete, pungent, auricles are absent; flowers are in stalked panicles, and seeds contain appendages (Townsend and Guest, 1985).

J. rigidus Desfontaines, 1798 grows in marshes, shallow brackish water, and semi-saline soil and can be found in a variety of moist, wet and temperate climates (Snogerup, 1978; Townsend and Guest, 1985).

J. rigidus species are used in traditional medicine for their antioxidant, antimicrobial, antitumor, cytotoxic, antiviral, anti-algal, and anti-inflammatory properties (El-Shamy et al., 2015). This genus contains several medically relevant compounds including terpenes, flavonoids, phenolic acids, coumarins, sterols, carotenoids, stilbenes and phenanthrenes. Seeds of this plant are rich in fatty acids and amino acids (Osman et al., 1975; Zahran and ElHabib, 1979).

Heavy metals are some of the most critically relevant environmental pollutants (Tangahu et al., 2011); the metals sources include natural rock erosion and human activities, for example, industrial processes go into unpolluted areas where they accumulate in the water, soil, deep sediment, and living organisms (Miretzky et al., 2004). Utilizing plants to remove this form of pollutants have been investigated since the early 1970s (Susarla et al., 2002; Bouldin et al., 2006).

Many plant species are well suited for phytoremediation due to their ability to absorb heavy metals such as $\mathrm{Pb}, \mathrm{Cd}, \mathrm{Cr}, \mathrm{Ag}$, and various radionuclides from soil (Lasat, 2000). Phytoremediation can remove heavy metals many (e.g., $\mathrm{Fe}, \mathrm{Mn}, \mathrm{Zn}, \mathrm{Cd}, \mathrm{Cr}, \mathrm{Pb}, \mathrm{Co}, \mathrm{Ag}, \mathrm{Se}$, $\mathrm{Hg}, \mathrm{Cu}, \mathrm{Mg}, \mathrm{Mo}$, and Ni) (Cho-Ruk et al., 2006); this technique uses plants to accumulate pollution, is affordable, and is environmentally friendly (Najeeb et al., 2017). Collection of plant species for phytoremediation purposes is related to, or depends on plants being in open biological systems with the latent to accumulate more heavy metal of dry biomass and growth rates, (Susarla et al., 2002; McGrath and Zhao, 2003). Plant uptakes of pollution from soil particles or soil liquid via root systems, and from cracks down of polluted sites from soils, sediments and water, and then they go through translocation and bioaccumulation to the internal plant structure (Cho-Ruk et al., 2006; Paz-Alberto and Sigua, 2013).

Many species of Juncus are used as accumulators; Juncus effuses Linnaeus, 1753, is one of the 17 terrestrial species that has ability to accumulate high concentrations of heavy metals like $\mathrm{Pb}, \mathrm{Cd}, \mathrm{Cu}$, and $\mathrm{Zn}$. In addition, to removes phyto-stabilization in wetlands through genetic manipulation (Yanqun et al., 2004; Grube et al., 2008; Najeeb et al., 2011; Najeeb et $a l ., 2017)$. This species was tolerant to stress from heavy metals such as zinc and chromium (Dimitroula et al., 2014; Mateos-Naranjo et al., 2014). 


\section{Hamza et al.}

The study area (Basrah City) contains developed industrial or urban regions which led to many environmental problems, and caused an increase in pollution, including heavy metals (Al-Obaidy et al., 2016). Many studies have evaluated and identified the sediment and water of the most pollution sites (Akesh, 2017). The influential heavy elements ( $\mathrm{Pb}, \mathrm{Cd}, \mathrm{Cr}$ and $\mathrm{Ni}$ ) are increasing in Basrah city because of its closeness to oil companies or industrial waste regions which contain high levels of metals such as oil refinery of Al-Sha'eiba (Khwedim et al., 2009).

The purpose of the present study was to determine the bioaccumulation of three heavy metals $\mathrm{Pb}, \mathrm{Cd}$, and $\mathrm{Ni}$ in the roots, culm, and leaves of J. rigidus, which have grown in different contaminated sites in Basrah in order to determine the applicability of J. rigidus for phytoremediation, and to observe the anatomical changes of roots and culm structure.

\section{Study area and sampling}

\section{MATERIALS AND METHODS}

Experiments were conducted at the College of Science, Department of Biology and Ecology, Basrah University. Three stations were selected: Station 1 included a control of uncontaminated area (Garmat Ali) Global Positioning System (GPS) 47 45 46" E $30^{\circ} 34$

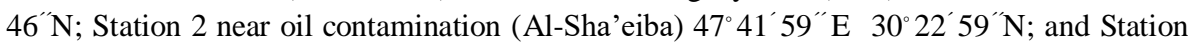
3 near energy engine contamination (Taga place) $47^{\circ} 45^{\prime} 58^{\prime \prime} \mathrm{E} 30^{\circ} 39^{\prime} 44^{\prime \prime} \mathrm{N}$.

J. rigidus specimens were collected in the summer of 2017 from the three stations and brought into the laboratory on the same day. Then, to remove the remaining soil from the plant materials, the specimens were washed carefully three times with distilled water to remove adhering particles/ remaining soil and then were dried. Chemical analysis of the heavy metals $(\mathrm{Cd}, \mathrm{Ni}$, and $\mathrm{Pb})$ in the roots, culm, and leaves of J. rigidus plant was achieved through $\mathrm{HNO}_{3}$ digestion and the final filtrated mixture was subjected to an atomic spectrophotometer (Phoenix-986, CITY, England).

The concentration of heavy metals detected in the plant was determined through comparison to a standard curve of concentrations (Kabata-Pendias and Pendias, 1992); the soil samples were collected at $0-15 \mathrm{~cm}$ depths, then the specimens dried in oven at $150{ }^{\circ} \mathrm{C}$ for 12 hours were digested in acid-cleaned Teflon microwave vessels hydrofluoric acid $2 \mathrm{ml}$ and $5 \mathrm{ml}$ of nitric acid and they were digested at $200^{\circ} \mathrm{C}$ for $30 \mathrm{~min}$ (Binning and Baird, 2001). Heavy metals content concentrations $(\mathrm{Pb}, \mathrm{Ni}$ and $\mathrm{Cd})$ were determined by using atomic spectrophotometer (Phoenix-986, CITY, England). The working wave lengths were as follows: $\mathrm{Pb} 217 \mathrm{~nm}$; $\mathrm{Cd}-228.8 \mathrm{~nm}$ and $\mathrm{Ni} 232 \mathrm{~nm}$ and limited of detection for each element: $\mathrm{Pb}, \mathrm{Ni}$ and $\mathrm{Cd}$ were $0.01 \mathrm{ppm}$.

\section{Phytoextraction efficiency}

Three parameters were calculated to compare the accumulation and translocation of heavy metals from the roots to the culms including: the bioconcentration factor (BCF), the translocation factor (TF), and the Biological Accumulation Coefficient (BAC) (Yoon et al., 2006). BCF is considered as the percentage of mineral concentration in roots to soil (Yoon et 
al., 2006). TF reflects the proportion of the heavy metals in the shoot to its roots whereas the BAC explains ratio of the heavy metals in the shoots to the soil (Cui et al., 2007; Li et al., 2007) as the following:

$\mathrm{BCF}=($ Concentration Metals $)$ root $/$ (Concentration Metals $)$ soil

$\mathrm{TF}=($ Concentration Metals) shoot $/$ (Concentration Metals) root

$\mathrm{BAC}=($ Concentration Metals $)$ shoot $/$ (Concentration Metals) soil

\section{Anatomical study}

For the anatomical studies, ten specimens of J. rigidus plants were collected from each station; the permanent sections of roots and culms were ready, the plant parts were cut into $10-15 \mathrm{~cm}$ pieces and fixed for 24 hours in formalin-acetic acid and alcohol (FAA) and were preserved in $70 \%$ ethyl alcohol, then dehydrated in an ethyl alcohol series. Then, specimens were sectioned on a rotary microtome, and stained in safranin and fast green before being mounted in Canada balsam on glass slides (Johansan, 1968). 100 slides were prepared from $J$. rigidus specimens in each station. In this study, unpolluted and polluted plant parts from stations were analyzed; the five best transverse sections were selected to study anatomical features. Finally, the specimens were examined with an Olympus light microscope and photographed with DCE-2 digital camera (Metcalfe and Chalk, 1950; Esau, 1977).

\section{Statistical analysis}

The data of the study were analyzed by one-way analysis of variance (ANOVA). A significance level $<0.05$ was considered statistically significant.

\section{RESULTS AND DISCUSSION}

The heavy metal concentrations in J. rigidus tissues of contaminated areas are shown in Table (1); the highest accumulation of the heavy metal was recorded in lead $12.50 \pm 3.58 \mathrm{mg}$ $\mathrm{kg}^{-1}$ and then nickel $(<0.30)$, the lowest value was recorded for cadmium $(<0.05)$. These results revealed that the plants accumulated great amounts of heavy metals; furthermore, the results indicated that the lead content of the J. rigidus plants surpassed the upper limits of the normal range (Tab. 1). These agree with the literature using other Juncus species for accumulation purposes (Deng et al., 2004; Weis and Weis, 2004; Yanqun et al., 2004).

Table (1): Average concentrations of Lead, Nickel and Cadmium in leaves of Juncus rigidus $\left(\mathrm{mg} \mathrm{kg}^{-1}\right)$ in Station 2.

\begin{tabular}{|c|c|}
\hline Metal & Concentration \\
\hline Lead & $12.50 \pm 3.58$ \\
\hline Nickel & $<0.30$ \\
\hline Cadmium & $<0.05$ \\
\hline
\end{tabular}

The total concentrations of lead in J. rigidus roots, leaves, and culm collected from polluted and unpolluted sites are illustrated in Table (2) and Diagram (1); the results showed that lead concentrations in J. rigidus varied in different locations and parts of the plant from undetectable in control to $12.66,19.33$, and $9.80 \mathrm{mg} \mathrm{kg}^{-1}$ in leaves, culm, and roots 


\section{Hamza et al.}

respectively from Station 2; and 10.76, 12.66, and $9.50 \mathrm{mg} \mathrm{kg}^{-1}$ in Station 3 (Tab. 2; Diag. 1). In J. rigidus specimens, heavy metal concentrations were higher in the culm than the root and leaves. This shows the ability of the plant to translocate pollution from roots to stems, similar to other plants (Han et al., 2016). A similar study from Hasanuzzaman et al. (2014) found that all of the halophytes exhibited better accumulation of salt, and the level of total salt accumulation in the shoot was mostly species-specific. The amount of heavy metal $(\mathrm{Pb}, \mathrm{Ni}$, and $\mathrm{Cd}$ ) in the tissues of J. rigidus is elevated because of the constant contact of the leaves and stems with the water or metal ions stored in the roots and then translocated to the shoots (Gupta et al., 2011).

The results agreed with Grube et al. (2008) study, which showed that some species of Juncus are sensitive to heavy metal stress. Lead is a highly toxic pollutant, and its higher concentrations cause reduced plant growth, speed up reactive oxygen species (ROS) production which enter in plant metabolic processes and damage cell membranes (Liu et al., 2008; Huang et al., 2008; Pourrut et al., 2011; Doncheva et al., 2013).

Survival of $J$. rigidus under heavy metal toxicity increased the level of anti-oxidative enzymes, metal prohibiting from shoots and cellular removal (Weis and Weis, 2004), and detoxification into the roots (Yanqun et al., 2004; Deng et al., 2004). In addition, the free $\mathrm{Pb}^{+2}$ ions in media inhibit enzymatic action by reacting with sulfhydryl groups (Seregin and Ivanov, 2001; Han et al., 2016).

Table (2): Translocation and bioconcentration factor of Lead concentration in Juncus rigidus collected from the contaminated (station 1 and 2) and control area in Basrah city.

\begin{tabular}{|l|l|l|l|l|l|l|c|}
\hline Area & $\begin{array}{l}\text { Leaves } \\
\mathrm{mg} \mathrm{kg}^{-1}\end{array}$ & $\begin{array}{l}\text { Culm } \\
\mathrm{mg} \mathrm{kg}^{-1}\end{array}$ & $\begin{array}{l}\text { Root } \\
\mathrm{mg} \mathrm{kg}^{-1}\end{array}$ & $\begin{array}{l}\text { Soil } \\
\mathrm{mg} \mathrm{kg}^{-1}\end{array}$ & BCF & TF & BAC \\
\hline Control(station 1) & $<\mathrm{LD}$ & $<\mathrm{LD}$ & $<\mathrm{LD}$ & - & - & - & - \\
\hline Shaiba (station 2) & 12.66 & 19.33 & 9.80 & 1.5 & 6.53 & 3.26 & 21.32 \\
\hline Taga(station 3) & 10.76 & 12.66 & 9.50 & 2 & 4.75 & 2.46 & 11.71 \\
\hline
\end{tabular}

< LD: below detection limit 


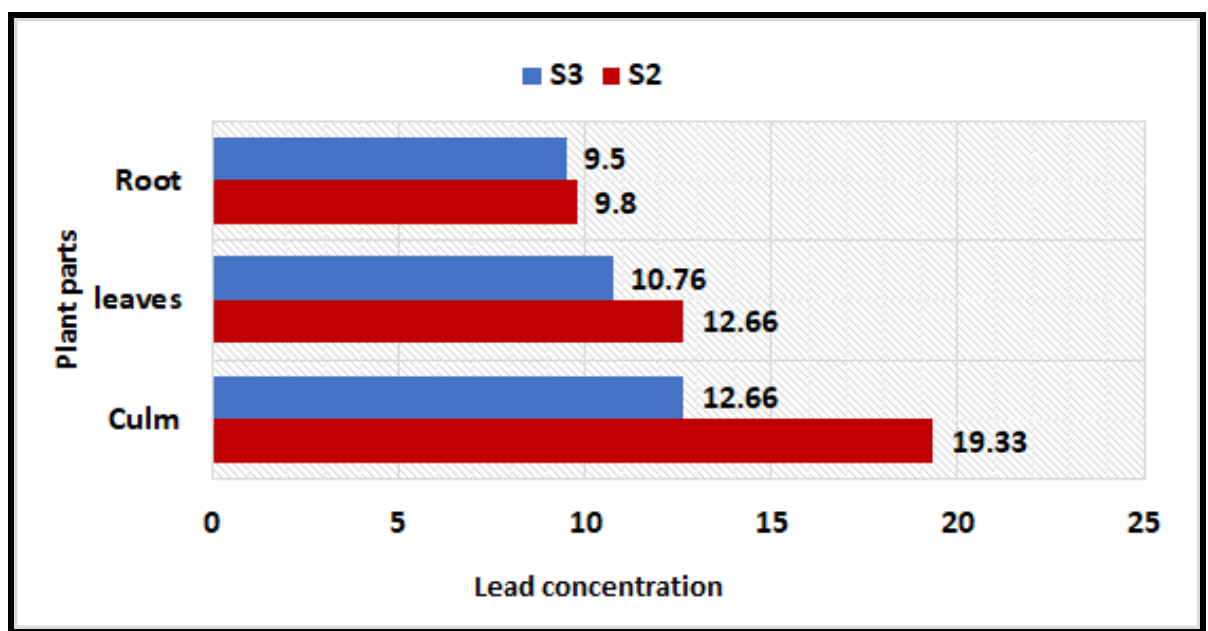

Diagram (1): Lead concentrations of the study parts in J. rigidus (in $\mathrm{mg} \mathrm{kg}^{-1}$ ).

\section{Phytoextraction efficiency}

The results for the TF, BCF, and BAC indicating the variation in lead concentration are given in Table (2). The results showed that $J$. rigidus had BCF, BAC and TF values greater than $>1$ and Pb's BAC values were the highest of the three metals (Tab. 2).

The results showed that it was easy for $J$. rigidus to translocate lead metal from its roots to its shoots; the TF values were 3.26 and 2.46 in Station 2 and Station 3, respectively which reflect that $J$. rigidus having a TF greater than $>1$; it is suitable for translocating metals from roots to shoots by phytoextraction and the plant doesn't confine metals to its roots (Yoon et al., 2006). According to Ghosh and Singh (2005), phytoextraction is a method to remove the pollution from the soil without destroying structure and fertility of the soil. J. rigidus had BCF over $>1$ for $\mathrm{Pb}, \mathrm{BCF}$ recorded 6.53 and 4.75 in Stations 2 and 3, respectively; this value showed that $J$. rigidus could be used for accumulating many of the metals from polluted sites.

Values of TF, BCF, and BAC over $>1$ reflect that J. rigidus is capable of phytoextraction and phytostabilization (Yoon et al., 2006; Li et al., 2007). Phytostabilization uses plants to decrease the mobility and bioavailability of pollutants present in soil, and reduces the potential of toxins entering the food chain, where they can cause harm to human health (Tangahu et al., 2011).The mechanism underlying metal accumulation may be detoxicated through the confiscation of heavy metal ions in vacuoles, where they bind with organic acids, proteins, and individual peptides using enzymes, the selective transport and uptake of ions, osmotic adaptation, and salt (La'zaro et al., 2006; Cui et al., 2007).

\section{Anatomical Studies}

Anatomical root changes in J. rigidus

The Anatomical changes in the plants grown in unpolluted and the polluted regions were observed (Tab. 3, Pl.1). Transverse sections of J. rigidus roots from polluted regions showed 


\section{Hamza et al.}

several changes in root structure, including diameter, aerenchyma tissue shape and arrangement of cortical parenchyma cells. The results showed a reduction in root thickness due to the accumulation of heavy metals. Root thickness was $1480.75 \mu \mathrm{m}$ on average in plants from the unpolluted area, while in the polluted sites were $170.33 \mu \mathrm{m}$ and $179.16 \mu \mathrm{m}$ respectively (Tab. 3). The transverse section of the roots has a one-cell thick epidermal layer, and epidermal cells in root in the unpolluted area were square-shaped or rectangular, uniseriate, and $90.83 \mu \mathrm{m}$ thick; while in the area of exposure, the roots were degraded and decreased in thickness down to $18.33 \mu \mathrm{m}$ (Tab. 3).

In unpolluted area, the cortex was composed of pseudohypodermis (hyperepidemis) layers and aerenchyma tissue (air spaces or lacunae). The pseudohypoderm was 3-6 cells thick in the unpolluted Station 1 and reduced in the polluted area to only one cell thick (Tab. 3, Pl.1). The results also showed changes in the shapes of cells, the root endodermis, exodermis and air spaces were reduced in the area exposed to pollution (Tab. 3); these changes in cell shape and tissue organization are likely because of the ability of pollution to disrupt the hormonal balance of $J$. rigidus or the poisonous effect of the metal, which can denature proteins quicken free radical's productions, and inhibit photosynthesis (Kabata-Pendias, 2011; Bini et al., 2012). Other investigators have reported that the exodermis and endodermis can serve as effective barriers to the movement of elements (Ederli et al., 2004; Wójcik et al., 2005; Najeeb et al., 2017).

Table (3): Measurement of root tissues in J. rigidus in micrometer $(\mu \mathrm{m})$.

\begin{tabular}{|c|c|c|c|c|c|c|}
\hline Station & $\begin{array}{c}\text { Root } \\
\text { diameter }\end{array}$ & $\begin{array}{c}\text { Epidermis } \\
\text { thickness }\end{array}$ & $\begin{array}{c}\text { Air chamber } \\
\text { thickness }\end{array}$ & $\begin{array}{c}\text { Vascular } \\
\text { bundle } \\
\text { thickness }\end{array}$ & $\begin{array}{c}\text { Xylem } \\
\text { thickness }\end{array}$ & $\begin{array}{c}\text { Number } \\
\text { of } \\
\text { xylem } \\
\text { row }\end{array}$ \\
\hline \hline 1 & $(1120-1520)$ & $(50-112.5)$ & $(800-1160)$ & $(125-142.5)$ & $(42.5-70)$ & $18-25$ \\
& 1480.75 & 90.83 & 975.32 & 135.11 & 16.78 & \\
\hline 2 & $(100-225)$ & $(30-60.21)$ & $(93.75-500)$ & $(70-80)$ & $(25-50)$ & $7-11$ \\
& 170.33 & 37.50 & 182.81 & 77.55 & 39.91 & \\
\hline 3 & $(150-200)$ & $(10-25)$ & $(50-100)$ & $(200-225)$ & $(20.5-30.5)$ & $6-8$ \\
& 179.16 & 18.33 & 66.87 & 210.62 & 33.33 & \\
\hline
\end{tabular}

In the pollution area, the cortex decreased in the size and amount of the intercellular spaces in the aerenchyma layer (Pl.1); the most pronounced anatomical feature of $J$. rigidus was the presence of gas-filled chambers and passageways in the roots called diaphragms. The aerenchyma layer from the control area was regular and divided transversally by multiseriate diaphragms, irregular intercellular spaces spreading through the leaf and long distances through the roots $(975.32 \mu \mathrm{m})$, while decreased in thickness $(66.87 \mu \mathrm{m})$ and became irregular and undulate in shape (Tab. 3, Pl. 1). These chambers provide an internal atmosphere for the plant and act as a source of the oxygen produced during photosynthesis and the carbon dioxide from respiration that accumulates and used in photosynthesis. Furthermore, aerenchyma provides buoyancy for the organs. The decrease in the number and size of the conducting elements of the xylem and phloem increases retention during the transport of 


\section{A study of physical and anatomical characteristics}

water and mineral salts; this is particularly needed when the plant undergoes stress (Alves $e t$ al., 2001). The present results are consistent with Gomes et al. (2011) who reported that lead can accumulate in the aerenchyma, which had observable levels of metals as well, there were some metals accumulated in the cell walls and aerenchyma of the cortical parenchyma of the roots $(\mathrm{Pl} .1)$.
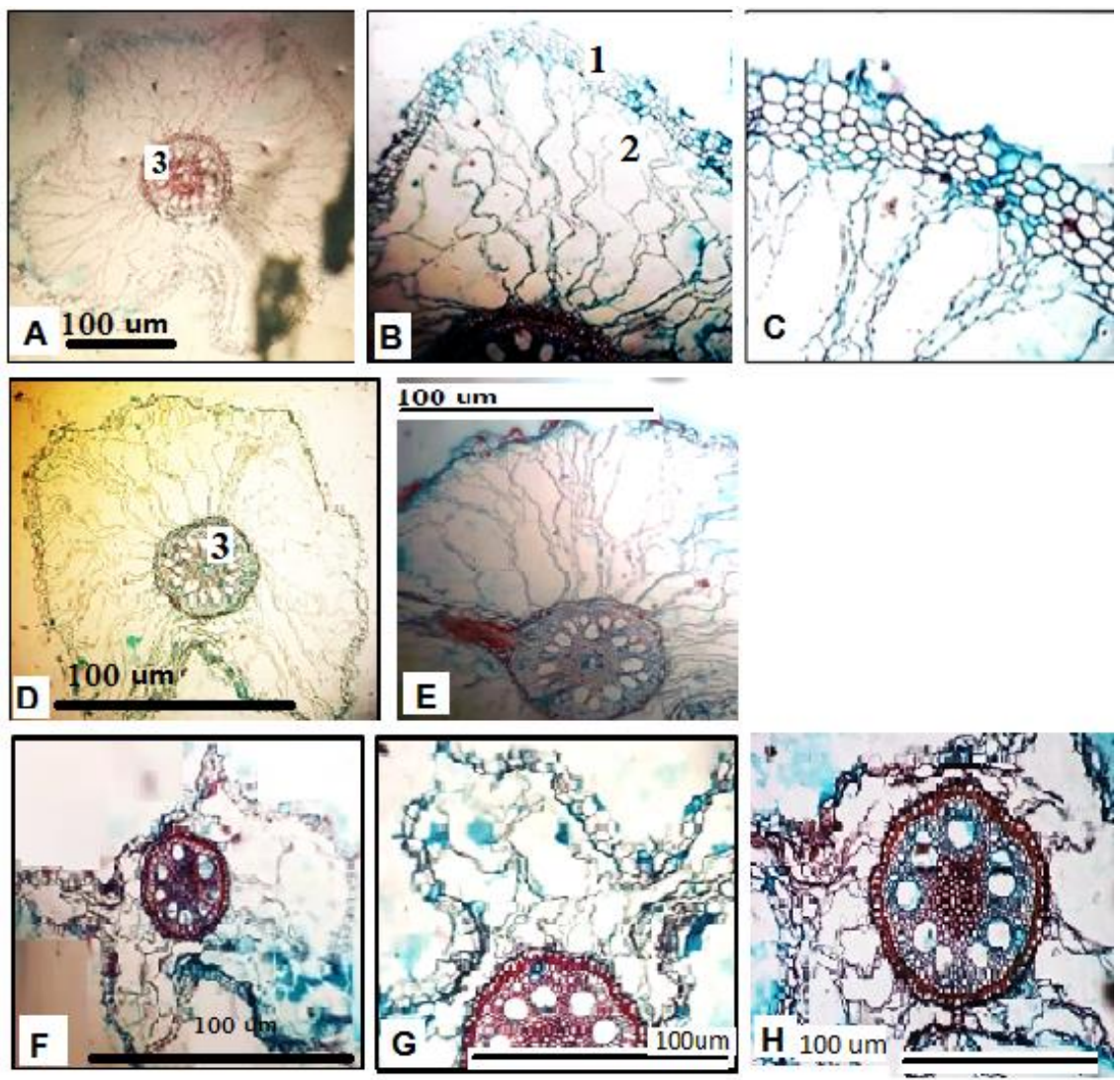

Plate (1): Cross section of Juncus rigidus root; (A) Whole root, (B) Aerenchyma tissue, (C) Epidermis and hypodermis layers, (D, E) Pollution area in station 3, (F, G, H) Oil polluted area, (F) Redaction and damage of aerenchyma tissue, the root abnormal, as well as reduced the number of vessels bundles, (G) Aerenchyma tissue, $(\mathrm{H})$ Some oil pollutant inside the xylem vessels and cells of roots, damage aerenchyma. (1- Epidermis, 2- Aerenchyma tissue, 3- Vascular bundle).

A pericycle layer occurred within the endodermis (Pl. 2); the outer part of pericycle layer was composed of a layer of irregular or hexagonal cells, 3-9 cells thick in the control area; it had very thick inner and anticlinal walls and thin outer walls. In spite of their role in pollutants reduction, an adverse effect in plant structure had been occurred; represented by changes in the internal structure of the root tissue, as well as the epidermis, cortex and 


\section{Hamza et al.}

endodermis become undifferentiated. The vascular bundle of J. rigidus in the polluted regions (Station 2) near the oil pollution showed that the cells, vessels of xylem, and pith are filled with oil contamination; our study found a reduction in the number and structure of phloem and xylem. Thickness of vascular bundle was $77.55 \mu \mathrm{m}$ (Tab. 3, Pl. 2). Similar results were recorded in terrestrial and aquatic plants by Weryszko-Chmielewska and Chwil (2005) and Al-Saadi et al. (2013). Other studies reported that a reduction in vascular bundle was due to the accumulation and translocation of heavy metals in the cell wall system (MacFarlane and Burchett, 2000; Weryszko-Chmielewska and Chwil, 2005; Al-Saadi et al., 2013). In contrast, in Station 3, the thickness of the vascular bundle was $210.62 \mu \mathrm{m}$ higher than in unpolluted areas and Station 2 (Tab. 3, Pl. 2). In addition, the vascular bundles lost their shape in the roots of plants exposed to pollution (Pl. 2).

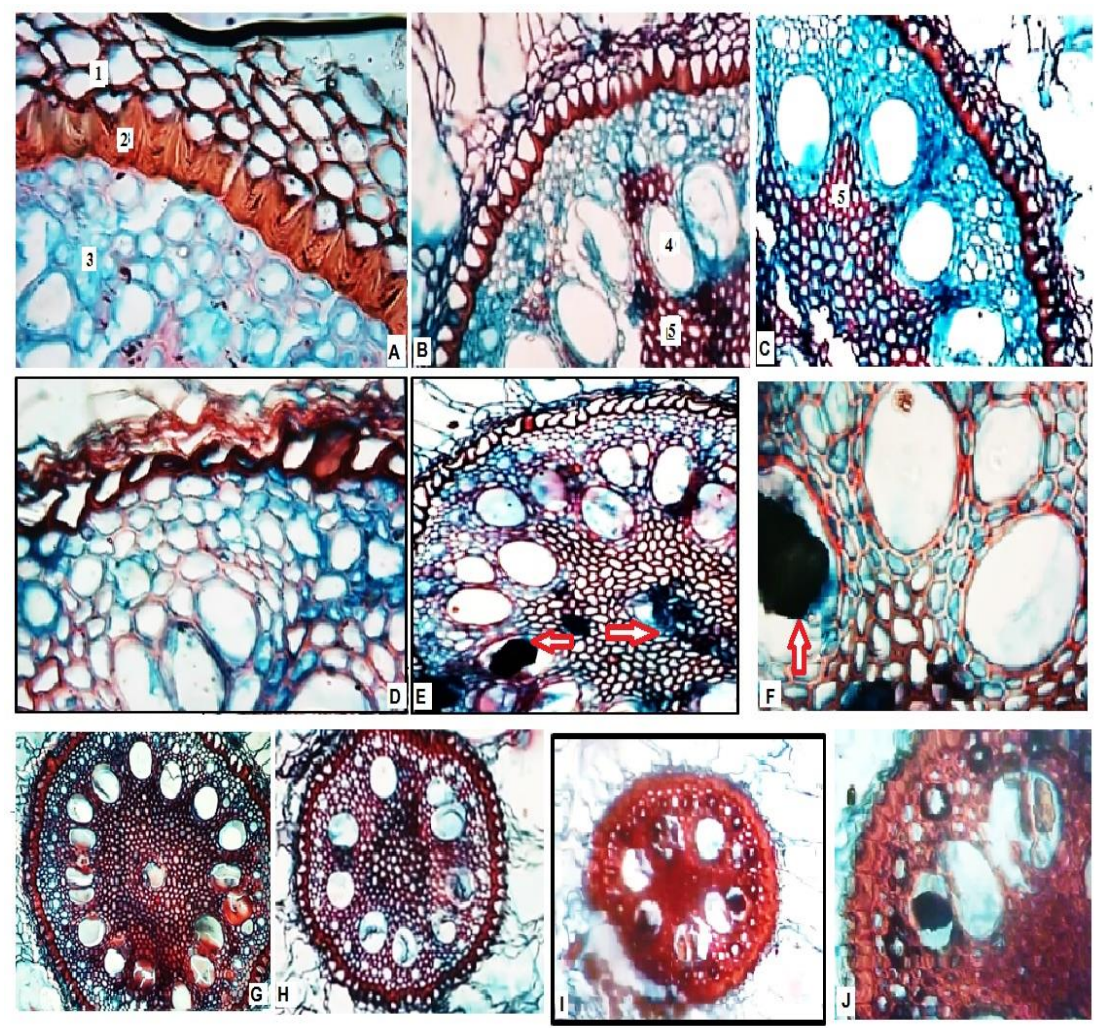

Plate (2):Cross-section of root of Juncus rigidus; (A) Non-polluted area, (B-J) Contaminated area, (B-C) Increased sclerenchyma inside the pith towered pericycle, (D) Abnormal and damage endodermis and pericycle, (E, F) Found some oil accumulate in pith and xylem vessels and cell roots, $(\mathrm{G}, \mathrm{H})$ Increased sclerenchyma in pith, (I-J) Showed reduction of vascular bundle, decreased number of the vascular bundle and present with black oil pollution inside both xylem vessels and cells of roots. 
A study of physical and anatomical characteristics

\section{Transverse sections of Culm}

Anatomical changes in J. rigidus culm between plants grown in Station 1 (unpolluted) and polluted areas (Station 2 and 3) were observed (Pl.3). In the unpolluted area, the culm contained a single layer epidermis. Chlorenchyma was found beneath the epidermis, 2-5 cells in thick, irregular, and rounded cells and then found continuous parenchyma called conjunctive tissue, which consisted of diaphragms of stellate or branching cells. The stele is scattered, with fewer but bigger vascular bundles, which were atactostele (P1.3A).

The results showed a reduction in the culm of J. rigidus specimens collected from polluted areas; the specimens taken from areas polluted with oil had accumulated pollutants in their epidermis and in some cells of culm. Moreover, high levels of pollution were observed in the bundles; it was the small size increased in sclerenchyma, and appeared of darker color compared to the samples grown in the control area $(\mathrm{Pl} .3 \mathrm{~B}, \mathrm{E}, \mathrm{H})$, the same thing was reported by Sridhar et al. (2007), Gomes et al. (2011) and Bini et al.(2012). The decrease in the culm belongs to the toxic effect of the pollution, which can inactivate proteins and motivate the production of free radical's heavy metals which can constrain photosynthesis, necrosis and growth inhibition of the plant (Kabata-Pendias, 2011; Bini et al., 2012). The metals damage the plant by inhibiting cell division and disintegrating the parenchyma (Gomes et al., 2011). Plants found near the area polluted by oil exhibit a decrease in growth rate and changes in structure of cells and tissues. The sensitivity of Juncus species for oil remediation is broad and depends on the morphological characteristics and components of the soil. However, some studies reported that J. maritimus Lamarck, 1789 and J. subsecundus N. A. Wakefield,1957 are very important for resolving hydrocarbon pollution which it was explored along with a reduction in growth rate at high concentration (Zhang et al., 2010; Mnpfs et al., 2011; Anderson and Hess, 2012; Michel and Rutherford, 2014).

The epidermis is composed of one layer of cells; the thickness of the epidermis of unpolluted region was $4.64 \mu \mathrm{m}$, while it reached to $9.50 \mu \mathrm{m}$ in Station 3. Lower thickness was recorded in station 2 (Tab. 4, Pl. 3). The cuticular layer develops in the extracellular space; this was thicker in the polluted areas. Below the epidermis in the outer part of the cortex, the observed chlorenchyma had 6- 13 various cellular layers with elongated cells that were slightly swollen in the control area, while it was 1-3 layers in Stations 2 and 3 as detailed in Table (4) and Plate (3).

In control, the vascular bundle was collateral, and the phloem of the vascular bundles was outer to the xylem followed by the phloem; the arrangement of the vascular tissue within the leaf resembles that of an atactostele. The sclerenchyma layer was observed surrounding the vascular bundle; in polluted regions, there was a reduction in the size, number and quantity of the vessel element of $J$. rigidus. These results validate with Weryszko-Chmielewska and Chwil (2005) and Al-Saadi et al. (2013); these studies showed a decrease in the number and dimension of the vessel elements. Some investigators reported that the inhibition of growth and reduction in xylem may be due to the accumulation of heavy metals in the walls and air canals which (comprises cells with large intercellular spaces that allow the air supply to underwater plant parts in the control area and make up the cortex and the pith) were destroyed 


\section{Hamza et al.}

and disappeared (Weryszko-Chmielewska and Chwil, 2005; Al-Saadi et al., 2013; Brandao et al., 2018).

Yoon et al. (2006) and Brandao et al. (2018) have assessed the potential for phytoremediation with plant species growing on a polluted area and, noticed that the concentration of $\mathrm{Pb}$ was highest in the roots of plants; this study found higher $\mathrm{Pb}$ concentrations in the shoots compared to other metals. Reduction of the toxicity of heavy metals is the compartmentalization of metals in vacuoles strategy used by the plants (Ali et al., 2013; Brandao et al., 2018).

Changes in roots and culm tissues also support to understand the treat of metal buildup and tolerance; the absorption of these metals from the soil is closely connected to the root and culm transpiration rate. The effects of $\mathrm{Pb}, \mathrm{Cd}$ and $\mathrm{Ni}$ on the root and stem anatomy are somewhat similar to the results reported by Srighar et al. (2005) and Vollenweider et al. (2006).

Table (4): Measurement of culm tissues in J. rigidus in micrometer $(\mu \mathrm{m})$.

\begin{tabular}{|c|c|c|c|c|c|}
\hline Position & $\begin{array}{c}\text { Culm } \\
\text { thickness }\end{array}$ & $\begin{array}{c}\text { epidermis } \\
\text { thickness }\end{array}$ & $\begin{array}{c}\text { Xylem } \\
\text { thickness }\end{array}$ & $\begin{array}{c}\text { Phloem } \\
\text { thickness }\end{array}$ & $\begin{array}{c}\text { Vascular } \\
\text { bundle } \\
\text { thickness }\end{array}$ \\
\hline S 1 & $(112.5-150)$ & $(2.5-5.5)$ & $(10-17.5)$ & $(17.5-40)$ & $(30-60)$ \\
& 132.91 & 4.64 & 12.08 & 31.25 & 48.05 \\
\hline S 2 & $(45-100)$ & $(4.5-5.5)$ & $(11-20)$ & $(22-35)$ & $(10-30)$ \\
& 75.33 & 4.30 & 13.54 & 20.40 & 22.50 \\
\hline S 3 & $(31-95)$ & $(6.55-12)$ & $(13-22)$ & $(15-30)$ & $(21-40)$ \\
& 40.22 & 9.50 & 14.70 & 20.21 & 24.88 \\
\hline
\end{tabular}



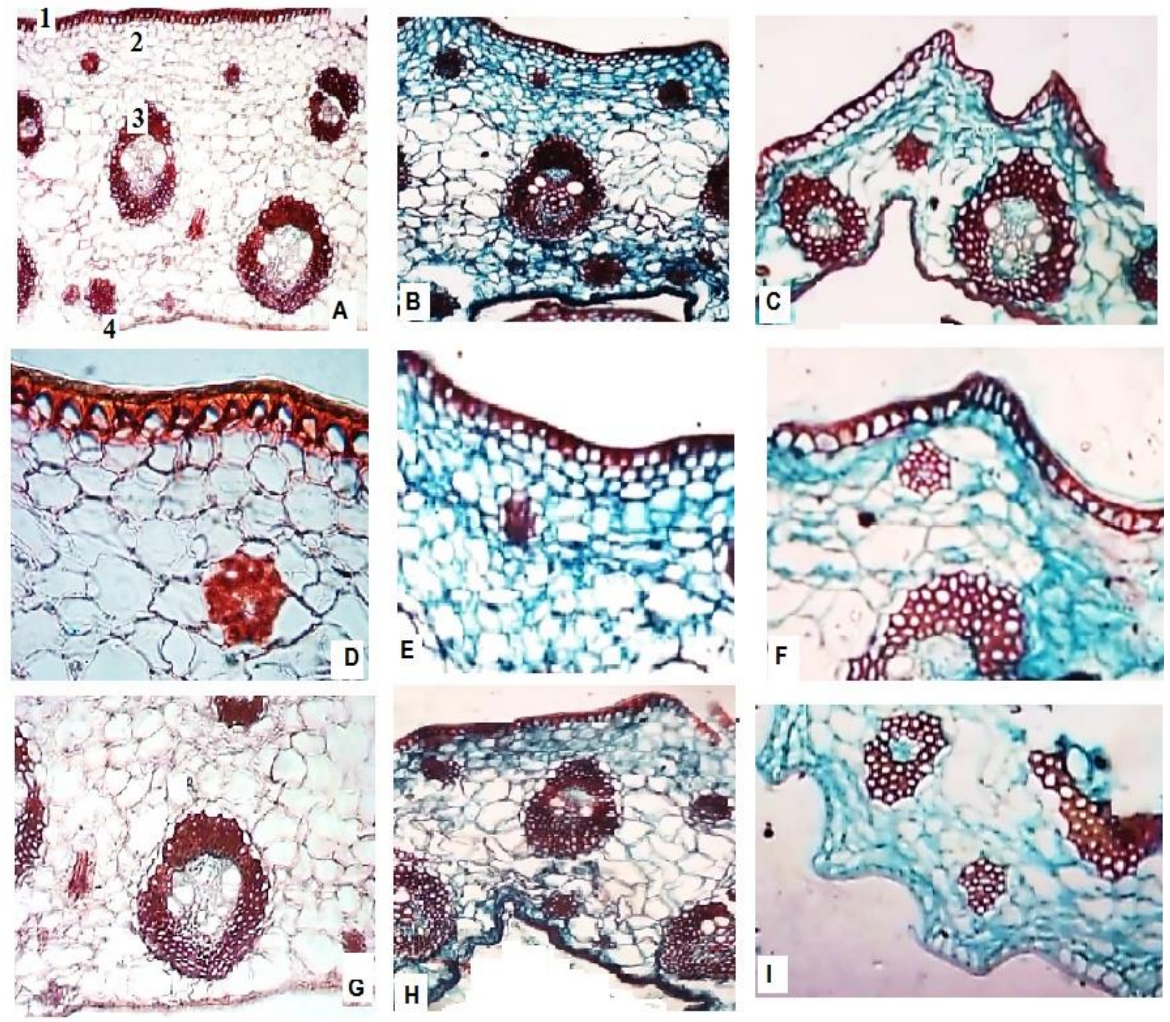

Plate (3): Cross section of the culm of Juncus rigidus; (A, D, G) Non-pollution area, (BE, H) Polluted area in station 2, (C, F, I) Pollution in station 3. (1-Epidermis, 2Chlorenchyma layer, 3- Vascular bundle).

\section{CONCLUSIONS}

J. rigidus can be expanded for the phytostabilization in polluted sites by heavy metals at each of the salvage steps; it was effective in taking up $\mathrm{Pb}, \mathrm{Ni}$, and $\mathrm{Cd}$ metals, with BCFs all observed above one. Our results reported that J. rigidus presented adaptive features for survival in soil polluted with heavy metals, suggesting that $J$. rigidus can be grown in polluted regions with these metals. High translocation factor, metal concentration ratio in plant shoots to roots is indicative of and internal detoxification metal tolerance system; thus, they have the potential for phytoextraction.

\section{LITERATURE CITED}

Akesh, A. A. 2017. Analytical study for heavy metals pollution in surface water and sediments for selected rivers of Basrah governorate. Kufa Journal of Engineering, 8(2): $105-118$. 


\section{Hamza et al.}

Ali, H., Khan, E. and Sajad, M. A. 2013. Phytoremediation of heavy metals concepts and applications. Chemosphere, 91:869-881.

Al-Obaidy, A. H., Al-Janabi, Z. Z. and Al-Mashhady, A. M. 2016. Distribution of some heavy metals in sediments and water in Tigris River. Journal of Global Ecology and Environment, 4(3):140-146.

Al-Saadi, S. A. M., Al-Asaadi, W. M. and Al-Waheeb, A. N. 2013. The effect of some heavy metal's accumulation on physiological and anatomical characteristic of some Potamogeton L. plant. Journal of Ecology and Environmental Sciences, 4 (1):100 108.

Alves, E. S., Giusti, P. M., Domingos, M., Saldiva, P. H. N., Guimara, E. T. and Lobo, D. J. A. 2001. Anatomic studies on Tradescantia hibrid clone 4430 leaves: changes caused by urban air pollution. Brazilian Journal of Botany, 24(4):561-566.

Anderson, C. J. and Hess, T. A. 2012. The effects of oil exposure and weathering on blackneedle rush (Juncus roemerianus) marshes along the Gulf of Mexico. Marine Pollution Bulletin, 64:2749-55.

Bini, C., Wahsha, M., Fontana, S. and Maleci, L. 2012. Effects of heavy metals on morphological characteristics of Taraxacum officinale Web growing on mine soils in NE Italy. Journal of Geochemical Exploration, 123:101-108.

Binning, K. and Baird, D. 2001. Survey of heavy metals in the sediments of the Swartkops River Estuary, Port Elizabeth, South Africa. Water, 27: 461-466.

Bouldin, J. L., Farris, J. L., Moore, M. T., Smith, J. R and Cooper, C. M. 2006. Hydroponic uptake of atrazine and Lambda- cyhalothrin in Juncus effuses and Ludwigia peploides. Chemosphere, 65: 1049-1057.

Brandao, M. C., Martins, F. M., Accioly, A. M., Santos, N. M., Roma M. V. and Azevedo, A. D. 2018. Phytoremediation potential and morphological changes of plants growing in the vicinity of lead smelter plant. International Journal of Environmental Science and Technology, 15:361-372.

Cho-Ruk, K., Kurukote, J., Supprung, P. and Vetayasuporn, S. 2006. Perennial plants in the phytoremediation of lead contaminated soils. Biotechnology, 5(1): 1-4.

Cui, S., Zhou, Q. and Chao. L. 2007. Potential hyper-accumulation of $\mathrm{Pb}, \mathrm{Zn}, \mathrm{Cu}$ and $\mathrm{Cd}$ in endurant plants distributed in an old smeltery, northeast China. Environmental Geology, 51: 1043-1048. 
A study of physical and anatomical characteristics

Deng, H., Ye, Z. H. and Wong, M. H. 2004. Accumulation of lead, zinc, copper and cadmium by 12 wetland plant species thriving in metal contaminated sites in China. Environmental Pollution, 132: 29-40.

Dimitroula, H., Syranidou, E., Manousaki, E., Nikolaidis, N. P., Karatzas, G. P. and Kalogerakis, N. 2014. Mitigation measures for chromium-VI contaminated groundwater - The role of endophytic bacteria in rhizofiltration. Journal of Hazardous Materials, 281: 114-120.

Doncheva, S., Moustakas, M., Ananieva, K., Chavdarova, M., Gesheva, E., Vassilevska, R. and Mateev, P. 2013. Plant response to lead in the presence or absence EDTA in two sunflower genotypes (cultivated $\mathrm{H}$. annuus cv. 1114 and interspecific line $\mathrm{H}$. annuus $\mathrm{x}$ H. argophyllus). Environmental Science and Pollution Research, 20 (2): 823-833.

Ederli, L., Reale, L., Ferranti, F., Pasqualini, S. 2004. Responses induced by high concentration of cadmium in Phragmites australis roots. Physiologia Plantarum, 121: 66-74.

El-Shamy, A. I., Abdel-Razek, A. F. and Nassar, M. I. 2015. Phytochemical review of Juncus L. genus (Fam. Juncaceae). Arabian Journal of Chemistry, 8 (5):614-623.

Esau, K. 1977. Anatomy of seed plants, John Wiley and Sons, New York, 550.

Ghosh, M. and Singh, S. P. 2005. A review on phytoremediation of heavy metals and utilization of its byproducts, Applied Ecology and Environmental Research, 3(1): 1-18.

Gomes, M. P., Marques, T. C., Nogueira, M. O., Castro, E. M. and Soares, A. M. 2011. Ecophysiological and anatomical changes due to uptake and accumulation of heavy metal in Brachiaria decumbens. Scientia Agricola, 68:566-573.

Grube, R. H., Wiessner, A., Kuschk, P., Kaestner, M. and Appenroth, K. J. 2008. Physiological responses of Juncus effusus (Rush) to chromium and relevance for wastewater treatment in constructed wetlands. International Journal of Phytoremediation, 10: 79-90.

Gupta, K., Gaumat, S. and Mishra, K. 2011. Chromium accumulation in submerged aquatic plants treated with tannery effluent at Kanpur, India. Journal of Environmental Biology, 32(5):591-597.

Han, Y., Zhang, L., Yang, Y., Yuan, H., Zhao, J., Gu, J. and Huang, S. 2016. Pb uptake and toxicity to Iris halophila tested on $\mathrm{Pb}$ mine tailing materials. Environmental Pollution, 214: 510-516. 
Hamza et al.

Hasanuzzaman, M., Nahar, K., Alam, M., Bhowmik, P. C., Hossain, M., Rahman, M., Prasad, M. N., Ozturk, M. and Fujita, M. 2014. Potential use of Halophytes to Remediate Saline Soils. BioMed Research International, 1-12. https://doi.org/10.1155/2014/589341

Huang, H., Li, T., Tian, S., Gupta, D.K., Zhang, X. and Yang, X. E. 2008. Role of EDTA in alleviating lead toxicity in accumulator species of Sedum alfredii H. Bioresource Technology, 99 (14): 6088-6096.

Johansan, D. A. 1968. Plant Microtechnique, McGraw Hill, New York, 487 pp.

Kabata-Pendias, A. 2011. Trace elements in soils and plants. Chemical Rubber Company Press, Boca Raton, 201-213.

Kabata-Pendias, A. and Pendias, H. 1992. Trace elements in soils and plants. $2^{\text {nd }}$ Edition, CRC Press. Boca Raton, 365 pp.

Khwedim, K. H., Al- Anssari, H. R. and Al- Bassam, K.S. 2009. Study of distribution of some heavy metals in the soil of Basra city south of Iraq. Iraqi Journal of Science, 50(4): 533-543.

La'zaro, D. J., Kiddb, P. S. and Martýneza, C. M. 2006. A phytogeochemical study of the Tra's-os Montes region (NE Portugal): Possible species for plant-based soil remediation technologies. Science of the Total Environment, 354: 265- 277.

Lasat, M. M. 2000. Phytoextraction of metals from contaminated soil: a review of plant/soil/metal interaction and assessment of pertinent agronomic issues. Journal of Hazardous Substance Research, 2: 1-25.

Li, M. S., Luo, Y. P. and Su. Z. Y. 2007. Heavy metal concentrations in soils and plant accumulation in a restored manganese mine land in Guangxi, South China. Environmental Pollution, 147: 168-175.

Liu, D., Li, T.Q., Jin, X. -F., Yang, X. E., Islam, E. and Mahmood, Q. 2008. Lead induced changes in the growth and antioxidant metabolism of the lead accumulating and nonaccumulating ecotypes of Sedum alfredii. Journal of Integrative Plant Biology, 50: 129-140.

MacFarlane, G. R. and Burchett, M. D. 2000. Cellular distribuition of copper, lead and zinc in the grey mangrove, Avicennia marina (Forsk.) Vierh. Aquatic Botany, 68: 45-59.

Mateos-Naranjoa, E., Castellanos, E.M. and Perez-Martinca, A. 2014. Zinc tolerance and accumulation in the halophytic species Juncus acutus. Environmental and Experimental Botany, 100: 114-121. 
A study of physical and anatomical characteristics

McGrath, S. P. and Zhao, F. 2003. Phytoextraction of metals and metalloids from contaminated soils. Current Opinion in Biotechnology, 14: 277-282.

Metcalfe, C. R. and Chalk, L. 1950. Anatomy of the Monocotyledons, Oxford at the Clarendon Press, 470pp.

Michel, J. and Rutherford, N. 2014. Impacts, recovery rates, and treatment options for spilled oil in marshes. Marine Pollution Bulletin, 82:19-25.

Miretzky, P., Saralegui, A. and Cirelli, A. F. 2004. Aquatic macrophytes potential for the simultaneous removal of heavy metals (Buenos Aires, Argentina). Chemosphere, 57: 997-1005.

Mnpfs, C. and Basto, M. C. P. 2011. Vasconcelos MTSD. Suitability of different salt marsh plants for petroleum hydrocarbons remediation. Chemosphere, 84:1052-1057.

Najeeb, U., Ahmad, W., Zia, M. H., Zaffar, M. and Zhou, W. 2017. Enhancing the lead phytostabilization in wetland plant Juncus effusus L. through somaclonal manipulation and EDTA enrichment. Arabian Journal of Chemistry, 10: 3310-3317.

Najeeb, U., Jilani, G., Ali, S., Sarwar, M., Xu, L. and Zhou, W. 2011. Insights into cadmium induced physiological and ultra-structural disorders in Juncus effuses L. and its remediation through exogenous citric acid. Journal of Hazardous Materials, 186: 565574. Osman, F., Zahran, M. A. and Fayed, S. 1975. Potentialities of the seeds of flora of Egypt for oil production. Bulletin of the Faculty of Science. Cairo University, 3: 85-95.

Paz-Alberto, A. M. and Sigua, G. C. 2013. Phytoremediation: A green technology to remove environmental pollutants. American Journal of Climate Change, 2: 71-86.

Pourrut, B., Shahid, M., Dumat, C., Winterton, P. and Pinelli, E., 2011. Lead uptake, toxicity, and detoxification in plants. Reviews of Environmental Contamination and Toxicology, 213: 113-136.

Seregin, I. V. and Ivanov, V. B. 2001. Physiological aspects of cadmium and lead toxic effects on higher plants. Russian Journal of Plant Physiology, 48: 523-544.

Snogerup, S. 1978. Notes on Juncus for Flora Europaea. Botaniska Notiser, 131 (2): 185-187.

Sridhar, B. B. M., Han, F. X., Diehl, V. S., Monts, D. L. and Su, Y. 2007. Effects of Zn and $\mathrm{Cd}$ accumulation on structural and physiological characteristics of barley plants. Brazilian Journal of Plant Physiology, 19(1):15-22. 
Hamza et al.

Srighar, B. B. M., Diehl, S. V., Han, F. X., Monts, D. L. and Su, Y. 2005. Anatomical changes due to uptake and accumulation of $\mathrm{Zn}$ and $\mathrm{Cd}$ in Indian mustard (Brassica juncea). Environmental and Experimental Botany, 54: 131-141.

Susarla, S., Medina, V. F. and McCutcheon, S. C. 2002. Phytoremediation: an ecological solution to organic chemical contamination. Ecological Engineering, 18(5): 647-658.

Tangahu, B. V., Abdullah, S. R. S., Basri, H., Idris, M., Anuar, N. and Mukhlisin, M. 2011. A review on heavy metals $(\mathrm{As}, \mathrm{Pb}$, and $\mathrm{Hg}$ ) uptake by plants through phytoremediation. International Journal of Chemical Engineering, 21:1-31.

Townsend, C.C. and Guest,E. 1985. Flora of Iraq. V.8.Monocotyledons. Ministry of Agriculture and Agrarian Reform, Baghdad, 440 pp.

Vollenweider, P., Cosio, C., Günthardt-Goerg, M. and Keller, C. 2006. Localization and effects of cadmium in leaves of a cadmium-tolerant willow (Salix viminalis L.). II. microlocalization and cellular effects of cadmium. Environmental of Experimental Botany, 58: 25-40.

Weis, J. S. and Weis, P. 2004. Metal uptake, transport and release by wetland plants: implications for phytoremediation and restoration. Environment International, 30: $685-700$.

Weryszko-Chmielewska, E. and Chwil, M. 2005. Lead-Induced Histological and Ultrastructural Changes in the Leaves of Soybean Glycine max (L.) Merr. Soil Science and Plant Nutrition, 51(2):203-212.

Wójcik, M., Vangronsveld. J., D'Haen, J. and Tukiendorf, A. 2005. Cadmium tolerance in Thlaspi caerulescens. Environmental of Experimental Botany, 53: 163-171.

Yanqun, Z., Yuan, L., Schvartz, C., Langlade, L. and Fan, L. 2004. Accumulation of Pb, Cd, $\mathrm{Cu}$ and $\mathrm{Zn}$ in plants and hyperaccumulator choice in landing lead-zinc mine area. China. Environment Internatinal, 30: 567-576.

Yoon, J., Cao, X., Zhou, Q. and Ma, L. Q. 2006. Accumulation of $\mathrm{Pb}, \mathrm{Cu}$, and $\mathrm{Zn}$ in native plants growing on a contaminated Florida site. Science of the Total Environment, 368:456-464.

Zahran, M. A. and El-Habib, A. M. 1979. A phytochemical investigation of Juncus species. Bulletin faculty of science, Mansoura University, 5: 1-11.

Zhang, Z., Rengel, Z. and Meney, K. 2010. Polynuclear aromatic hydrocarbons (PAHs) differentially influence growth of various emergent wetland species. Journal of Hazardous Materials, 182: 689-95. 
در اسة الخصائص الفيزيائية و التشريحية لتر اكم المعادن الثقبلة في النوع Juncus rigidus Desfontaines, 1798 عائلة في محافظة البصرة ، جنوب العراق Juncaceae شذى محمد حمزة*، سحر عبد العباس مالك السعدي*

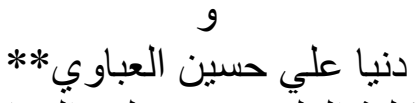

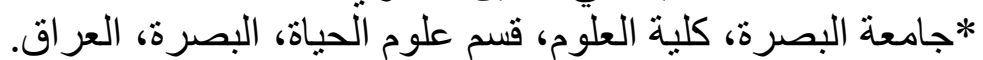

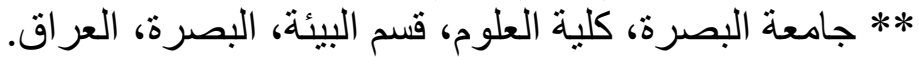

تأريخ الاستلام: 07 / 2020/01، تأريخ القبول: 04/11 /2020، تأريخ النشر: 06/24 2020

\section{الخلاصة}

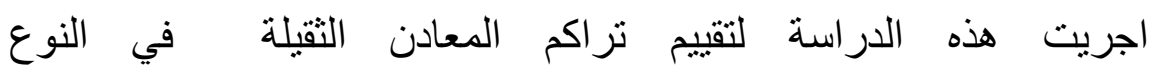
Juncus rigidus Desfontaines, 1798

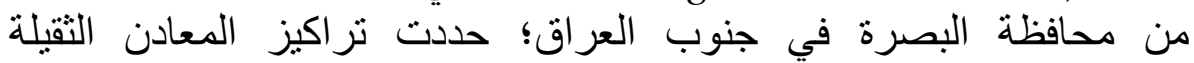
كالر صاص و النيكل والكادميوم من الجذور و السيقان و الأور اق في النبات.

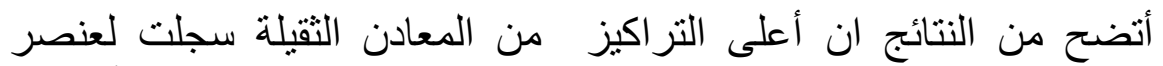

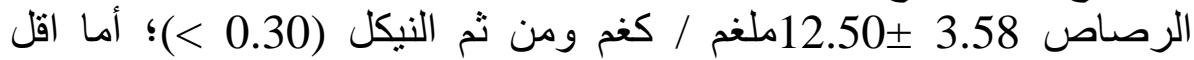

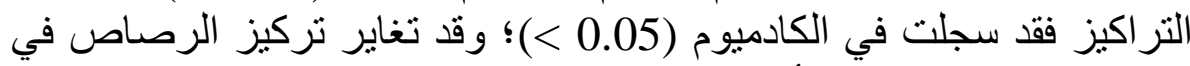

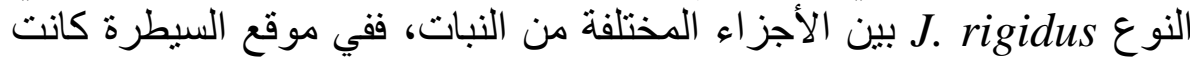

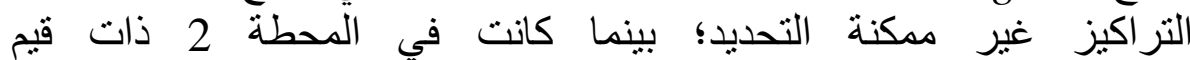

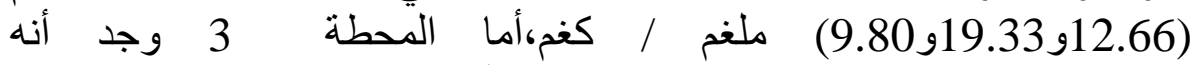
(10.76و12.66و 9.50) ملغم /كغم في الأوراق والسيقان والجذور على ملى التو اليث قيت قيم معامل النقل translocation factor ومعامل التركيز البايولوجي التيز (BAC) التركيز "الاحيائي(BCF (Bioconcentration Factor (BCF 
Hamza et al.

أظهرت نتائج الدر اسة التشريحية أن تر اكم المعادن الثقيلة في النبات أدى الى الى الثي

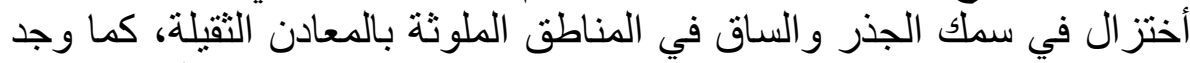

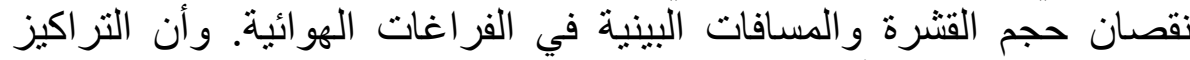

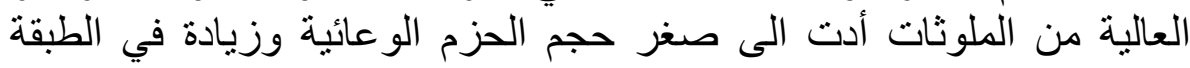

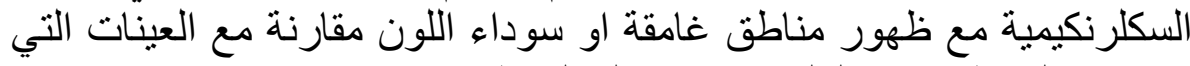
نمت في المناطق غير الملوثة في معاملة السيطرة. 